\title{
Discussion of 'Field evidence and hydraulic modeling of a large Holocene jökulhlaup at Jökulsá á Fjöllum channel, Iceland' by Douglas Howard, Sheryl Luzzadder-Beach and Timothy Beach, 2012
}

\author{
Jonathan L. Carrivick a,*, Fiona S. Tweed ${ }^{\text {b }}$, Paul Carling ${ }^{\text {c }}$, Petteri Alho ${ }^{\mathrm{d}}$, Philip M. Marren ${ }^{\mathrm{e}}$, Kate Staines ${ }^{\text {a }}$, \\ Andrew J. Russell ${ }^{\text {f }}$, E. Lucy Rushmer ${ }^{\mathrm{g}}$, Robert Duller ${ }^{\mathrm{h}}$ \\ a School of Geography, University of Leeds, Leeds, West Yorkshire, LS2 9JT, UK \\ ${ }^{\mathrm{b}}$ Geography and Environment, Staffordshire University, College Road, Stoke-on-Trent, ST4 2DE, UK \\ c Geography and Environment, Shackleton Building 44, University of Southampton, University Road, Southampton, SO17 1BJ, UK \\ ' Department of Geography and Geology, University of Turku, Turku FI-20014, Finland \\ e Department of Resource Management and Geography, The University of Melbourne, Parkville 3010, Australia \\ ${ }^{\mathrm{f}}$ School of Geography, Politics and Sociology, Daysh Building, University of Newcastle, Newcastle upon Tyne, NEI 7RU, UK \\ g Jacobs, 1 City Walk, Leeds, West Yorkshire, LS11 9DX, UK \\ ${ }^{\mathrm{h}}$ Department of Earth E' Ocean Sciences, School of Environmental Sciences, University of Liverpool, 4 Brownlow Street, Liverpool, L69 $3 G P$, UK
}

\section{A R T I C L E I N F O}

\section{Article history:}

Accepted 23 October 2012

Available online $\mathrm{xxxx}$

\section{Keywords:}

Jökulsá á Fjöllum

Iceland

Outburst flood

Landscape

Hydraulics

\begin{abstract}
A B S T R A C T
This paper discusses Howard et al. (2012) who reconstruct the peak discharge of a glacial outburst flood, or 'jökulhlaup', for part of the Jökulsá á Fjöllum in north-central Iceland. They propose that this flood was the largest on Earth. We consider that the magnitude of the jökulhlaup proposed by Howard et al. (2012) warrants much more robust field evidence and demands more carefully parameterised hydraulic modelling. For these reasons we firstly (i) present their study in the context of previous research (ii) highlight issues with attributing landforms and sediments to jökulhlaups, and (iii) consider uncertainty regarding the timing and magnitude of jökulhlaups along the Jökulsá á Fjöllum. We argue herein that whilst a range of landforms and sediments that are attributable to jökulhlaups can be observed along the Jökulsá á Fjöllum, these are not necessarily diagnostic of jökulhlaups. Secondly, we critically discuss (iv) the major underlying assumptions of their study, and (v) their calculations and subsequent interpretations. These assessments lead us to consider that the proposal by Howard et al. (2012) of the largest flood on Earth is highly unrealistic, especially when due consideration is given to a possible source area and a trigger mechanism.
\end{abstract}

(c) 2012 Elsevier B.V. All rights reserved.

\section{Introduction}

Howard et al. (2012) suggested that a glacial outburst flood or 'jökulhlaup' that routed along the Jökulsá á Fjöllum in northern Iceland during the early Holocene was the largest flood to have occurred on Earth. They present field data, most importantly large boulders, that they attribute to deposition by this flood and they use the elevation of these boulders to drive a hydraulic model that they suggest reasonably represents the characteristics of this flood. However, we feel that the field data as presented in their paper is both ambiguous and insufficient. We therefore briefly review the field evidence for, and research into, Jökulsá a Fjöllum jökulhlaups. Given the emphasis placed on the exceptional magnitude of the flood and on the applicability of the work for studies on Mars, we also feel that it is very important to question several assumptions that Howard et al. (2012) relied upon for their calculations. This paper therefore proceeds to discuss these

\footnotetext{
* Corresponding author. Tel.: +44 113343 3324; fax: +44 1133433308

E-mail address: j.l.carrivick@leeds.ac.uk (J.L. Carrivick).
}

assumptions, namely that: isolated large 'erratic' boulders are the product of jökulhlaup deposition, that the position and location of the boulders are sufficient to parameterise a step-backwater hydraulic model, that a hill named 'Ferjufjall' must have been overtopped, that Manning's $n$ can be treated as a fixed quantity, that modelling a single reach of the Jökulsá á Fjöllum can generate meaningful results, and finally that the volume of water implied by such a large peak discharge could have been sourced from northern Vatnajökull.

\section{Discussion of research on Jökulsá á Fjöllum jökulhlaups}

Attributing landforms and sediments to jökulhlaups (Table 1), particularly those jökulhlaups that occurred millennia ago, is far from straight forward and has occupied many major research efforts focused along the Jökulsá á Fjöllum (Table 2). In light of the claim by Howard et al. (2012) of new and extraordinary evidence, the most important of which is 'large boulders', we will herein firstly critically review the landscape upon which evidence of Holocene Jökulsá á Fjöllum jökulhlaups is superimposed. We will then highlight the production and redistribution 
Table 1

Summary of previous research identifying landforms and sediments along the course of Jökulsá á Fjöllum interpreted to be the product of jökulhlaups.

\begin{tabular}{|c|c|c|}
\hline \multirow[t]{2}{*}{ Author/publication year } & \multicolumn{2}{|c|}{ Landforms and sediments presented as evidence of Jökulsá á Fjöllum jökulhlaups } \\
\hline & Erosional & Depositional \\
\hline Alho et al. (2005) & $\begin{array}{l}\text { - Streamlined hills } \\
\text { - Scoured and plucked lava } \\
\text { - Large potholes } \\
\text { - } \text { Longitudinal grooves }\end{array}$ & $\begin{array}{l}\text { - Giant gravel bars } \\
\text { - Giant expansion bars } \\
\text { - Extensive surfaces of well-rounded heterolithic gravel } \\
\text { - Wash limits: erratic imbricated boulders }\end{array}$ \\
\hline $\begin{array}{l}\text { Knudsen and } \\
\text { Russell (2002) }\end{array}$ & $\mathrm{N} / \mathrm{A}$ & $\begin{array}{l}\text { - Large-scale sandy trough cross-bedded units capped by a boulder-rich unit, } \\
\text { interpreted as the product of a hyperconcentrated flow }\end{array}$ \\
\hline Waitt $(1998,2002)$ & $\begin{array}{l}\text { - Anastomosing water fluted and half pot-holed stripped basalt surfaces } \\
\text { - Small-scale scabland, dry cataracts } \\
\text { - Anastomosing distributary cols through moderate relief landscape }\end{array}$ & $\begin{array}{l}\text { - Huge boulders } \\
\text { - Long gravel bars } \\
\text { - Giant current dunes } \\
\text { - Graded gravel beds in channel } \\
\text { - Sand-silt backflood facies }\end{array}$ \\
\hline $\begin{array}{l}\text { Malin and Eppler } \\
\text { (1981) }\end{array}$ & $\begin{array}{l}\text { - Tear drop-shaped islands up to } 5 \mathrm{~km} \text { long } \\
\text { - Cataracts, scabland } \\
\text { - Broad lemniscate forms }\end{array}$ & $\begin{array}{l}\text { - Occasional megaripples } \\
\text { - Depositional tails } \\
\text { - Boulder fields } \\
\text { - Wash limits: 'debris lines' } \\
\text { - High water line overtopping large obstacles }\end{array}$ \\
\hline Tómasson (1973) & $\begin{array}{l}\text { - Ásbyrgi cataract } \\
\text { - Scabland } \\
\text { - Eroded crater rows }\end{array}$ & $\begin{array}{l}\text { - Shorelines } \\
\text { - Gravel-buried crater rows } \\
\text { - Large gravel bars }\end{array}$ \\
\hline Sæmundsson (1973) & $\begin{array}{l}\text { - Grooving and striations on smoothed lava surfaces beyond the } \\
\text { glaciation limit }\end{array}$ & $\mathrm{N} / \mathrm{A}$ \\
\hline
\end{tabular}

of large boulders in the landscape and then we will discuss the derivation and use of criteria to distinguish the genesis of jökulhlaup landforms amongst several key land surface processes.
Geological research along the Jökulsá á Fjöllum in Iceland was initiated to consider hydroelectric development (Thórarinsson, 1950, 1959; Helgason, 1987). Investigation of the Dettifoss canyon and of

Table 2

Summary of previous research suggesting timing and magnitude of jökulhlaups along the Jökulsá á Fjöllum.

\begin{tabular}{|c|c|c|c|c|c|c|}
\hline $\begin{array}{l}\text { Author/ } \\
\text { publication } \\
\text { year }\end{array}$ & \multicolumn{2}{|c|}{$\begin{array}{l}\text { Identified floods } \\
\text { (years ago) }\end{array}$} & $\begin{array}{l}\text { Estimated } \\
\text { peak discharge } \\
\left(\mathrm{m}^{3} \mathrm{~s}^{-1}\right)\end{array}$ & $\begin{array}{l}\text { Proposed source/generation } \\
\text { mechanism }\end{array}$ & $\begin{array}{l}\text { Acquired data/ } \\
\text { Interpretation method }\end{array}$ & Techniques \\
\hline $\begin{array}{l}\text { Kirkbride et al. } \\
\text { (2006) }\end{array}$ & \multicolumn{2}{|l|}{$\begin{array}{l}4100 \\
3500-2900\end{array}$} & $>7 \times 10^{5}$ & Kverkfjöll Grímsvötn & $\begin{array}{l}\text { 14C AMS dates from Betula } \\
\text { macrofossils within peat }\end{array}$ & $\begin{array}{l}\text { Field visit and laboratory } \\
\text { analysis }\end{array}$ \\
\hline $\begin{array}{l}\text { Alho et al. } \\
\text { (2005) }\end{array}$ & \multicolumn{2}{|l|}{$\mathrm{N} / \mathrm{A}$} & $0.9 \times 10^{6}$ & Barðabunga caldera & $\begin{array}{l}\text { PSIs: imbricated boulders and } \\
\text { washed bedrock (i.e. bedrock } \\
\text { with exotic well-rounded clasts) }\end{array}$ & Step-backwater modelling \\
\hline Waitt (2002) & \multicolumn{2}{|c|}{$\begin{array}{l}1 \times 2500-2000 \\
1 \times 9000-8000 \\
16 \times 8000-4000\end{array}$} & $\begin{array}{l}0.7 \times 10^{6} \\
\text { N/A }\end{array}$ & Kverkfjöll caldera & Stratigraphy and tephra (H5) & $\begin{array}{l}\text { Field visit, } 1986 \text { and } 2000 \\
\text { Geomorphological mapping } \\
\text { Step-backwater modelling }\end{array}$ \\
\hline Waitt (1998) & \multicolumn{2}{|c|}{2000} & $1 \times 10^{6}$ & $\mathrm{~N} / \mathrm{A}$ & Tephra (H5) & $\mathrm{N} / \mathrm{A}$ \\
\hline $\begin{array}{l}\text { Tómasson } \\
(1973,2002)\end{array}$ & \multicolumn{2}{|l|}{2500} & $0.4-0.5 \times 10^{6}$ & $\begin{array}{l}\text { 1973; Kverkfjöll caldera or } \\
\text { Grimsvötn by subglacial melting, } \\
\text { but most likely ice-dammed } \\
\text { lake south of Kverkfjöll } \\
\text { 2002; the Barðabunga caldera }\end{array}$ & Tephra (H3) & $\begin{array}{l}\text { Aerial photograph } \\
\text { interpretation and field visits } \\
\text { Manning equation, } \\
\text { flood-filled canyon and mea- } \\
\text { surement of present-day } \\
\text { topography }\end{array}$ \\
\hline $\begin{array}{l}\text { Sæmundsson } \\
\text { (1973) }\end{array}$ & \multicolumn{2}{|c|}{$\begin{array}{l}\text { Earliest post-glacial } \\
\text { Less than } 2900\end{array}$} & $\mathrm{~N} / \mathrm{A}$ & $\mathrm{N} / \mathrm{A}$ & $\begin{array}{l}\text { Lava striations location relative } \\
\text { to moraines of maximum glacial } \\
\text { extent }\end{array}$ & $\begin{array}{l}\text { Field visit Geomorphological } \\
\text { mapping }\end{array}$ \\
\hline $\begin{array}{l}\text { Thórarinsson } \\
\text { (1959) }\end{array}$ & \multicolumn{2}{|c|}{$\begin{array}{l}\text { 1490, } 1655 \text {; } \\
\text { Spring/early winter } 1684 ; \\
\text { early November } 1711 / 1712 \text {; } \\
\text { early winter } 1716 \text {; } \\
\text { September/October } 1717 \text {; } \\
\text { early September } 1729 \text {; August }\end{array}$} & & $\begin{array}{l}\text { Subglacial volcanic bursts in } \\
\text { the Kverkfjöll area and/or } \\
\text { Dyngjujökull }\end{array}$ & $\begin{array}{l}\text { Historical witness accounts from } \\
\text { Axarfjordur and Keldhuverfi }\end{array}$ & N/A \\
\hline $\begin{array}{l}\text { Thórarinsson } \\
\text { (1950) }\end{array}$ & \multicolumn{2}{|c|}{$\begin{array}{l}\text { 1655, 1684, 1711, 1712, 1776, } \\
1717,1729\end{array}$} & $\begin{array}{l}\text { Not likely to be } \\
>15,000 \\
1-1.5 \mathrm{~km}^{3}\end{array}$ & Dyngjujökull caldera/volcanogen & $\begin{array}{l}\text { Historical witness accounts from } \\
\text { Axarfjordur and Keldhuverfi }\end{array}$ & Field visit, 1946 to Kverkfjöll \\
\hline \multirow[t]{3}{*}{ Helgason (1987) } & Catastrophic & $\begin{array}{l}7100 \\
4600 \\
3000 \\
2000\end{array}$ & 400,000 & $\begin{array}{l}\text { Ice-dammed lake } \\
\text { 'Volcanism' }\end{array}$ & $\mathrm{N} / \mathrm{A}$ & $\mathrm{N} / \mathrm{A}$ \\
\hline & Hstoric & $\begin{array}{l}\text { Perhaps } 10 \text { floods } \\
\text { within a 'flood } \\
\text { period' of } \\
20-40 \text { years }\end{array}$ & 10,000 & Volcanic & $\mathrm{N} / \mathrm{A}$ & $\mathrm{N} / \mathrm{A}$ \\
\hline & Minor & $\begin{array}{l}\text { Approx. } 2 \text { per } \\
\text { century }\end{array}$ & 1500 & $\begin{array}{l}\text { Rapid spring thaw or other } \\
\text { 'special circumstances' }\end{array}$ & $\mathrm{N} / \mathrm{A}$ & $\mathrm{N} / \mathrm{A}$ \\
\hline
\end{tabular}


a dry canyon system at Ásbyrgi provoked controversy because the Jökulsá á Fjöllum is far too small in terms of its present and historic flood discharge to have formed such canyons (Tómasson, 1973; Malin and Eppler, 1981). Further analysis of Dettifoss and Ásbyrgi canyons showed that they were products of very large jökulhlaups (Thórarinsson, 1950; Sæmundsson, 1973; Tómasson, 1973; Waitt, $1998,2002)$. The scale of these canyons prompted comparisons of the Jökulsá á Fjöllum with (i) the Columbia plateau or Missoula floods (Tómasson, 1973; Waitt, 1998, 2002), (ii) with other terrestrial megafloods (Baker, 2002), and (iii) with outburst floods on Mars (Malin and Eppler, 1981; Baker, 2002; Chapman et al., 2003; Hovius et al., 2008) and brought awareness to the geological importance and deglacial association of jökulhlaups (c.f. Carrivick, 2011). Howard et al. (2012) were apparently motivated in their hydraulic modelling efforts by this analogy of the north-central Iceland landscape with that on Mars.

Subsequent research identified other landforms and sediments along the entire length of the Jökulsá á Fjöllum and attributed them to jökulhlaups. These landforms include dry waterfalls or 'cataracts', plucked-bedrock 'scablands' and bedrock flutings, and potholes (Table 1). Depositional landforms of the Jökulsá á Fjöllum jökulhlaups include boulders and gravel bars (Table 1). Most recent research has used the geomorphological and sedimentological evidence to inform hydraulic models, thereby enabling quantification of the inundation, peak discharge, behaviour and likely source of the Jökulsá á Fjöllum jökulhlaups (e.g. Alho et al., 2005, 2007; Carrivick, 2006, 2007a,b, 2009; Alho and Aaltonen, 2008).

Geomorphological evidence of Jökulsá á Fjöllum jökulhlaups is neither obvious nor coherent. This fact has been emphasised in the objective study to discriminate land cover characteristics in north-central Iceland by Alho (2003) and by a more localised but intensive mapping study across part of the southern (ice-proximal) reaches of the Jökulsá á Fjöllum: in Kverkfjallarani and Kverkfjöll, by Carrivick and Twigg (2005). Malin and Eppler (1981) were the first to draw caution to interpretations of the geomorphology of the Jökulsá á Fjöllum. They suggested that it could be difficult to distinguish between glacial and jökulhlaup debris at a single point as glacial deposits can be subrounded and jökulhlaup deposits can be subangular. Malin and Eppler (1981) pointed out that in 'unconfined' reaches, which can be up to 5-6 km wide (Tómasson, 1973), estimated that palaeo flow depths were reduced to a few metres, and therefore that flood effects were hard to distinguish.

Controversy also surrounds the limited sedimentary interpretations that have been made regarding the timing of jökulhlaups along the Jökulsá á Fjöllum. Waitt (1998) claimed that previously interpreted flood deposits in the lower canyon reaches of the Jökulsá á Fjöllum were of aeolian origin and even that some stratigraphy was man-made. Many jökulhlaups have been suggested to have occurred in the Jökulsá á Fjöllum system between 8000 and 3000 BP (Table 2). Use of tephrochronological methods has been restricted to the canyon localities within the distal reaches of the Jökulsá á Fjöllum (e.g., Kirkbride et al., 2006). Differing routeways of multiple jökulhlaups have led to differential preservation of jökulhlaup landforms and sedimentary deposits. Therefore it would be easy for single-site, or reach-based, analyses to be extrapolated erroneously. In our opinion, this is one of the causes for the ambiguity concerning the timing and magnitude of Jökulsá á Fjöllum jökulhlaups (Table 2).

\section{Holocene landscape evolution in north-central Iceland}

The last glaciation in Iceland probably began 110,000 years ago and ended about 11,000 years ago (Ingólfsson, 1994; Guðmundsson, 1997; Geirsdóttir et al., 2009). The modelling study of Hubbard et al. (2006) and geological evidence (Norðdahl, 1990; Geirsdóttir and Eiriksson, 1994) suggests that whilst at its maximum extent the last Iceland Ice Sheet reached beyond the present northern coast of Iceland. The Iceland Ice Sheet was dynamic, responsive, and influenced by oceanic as well as climatic forcing (Hubbard et al., 2006; Geirsdóttir et al., 2009); thereby providing a clear ability to produce (boulder-rich) glacigenic landforms and deposits. Volcanism in north-central Iceland was about 20-30 times greater at this time of deglaciation than at present because of a pressure release of pooled magma through differential tectonic movements from ice unloading (e.g., Slater et al., 1998; Maclennan et al., 2002). Consequently, subglacial and subaerial volcanic products including basalt ridge edifices and basalt entablature (both of which can collapse to large piles of boulders) - were emplaced across northcentral Iceland during the Last Glacial Maximum (LGM) (Carrivick et al., 2009a). Broadly coincident with the LGM, the rift zone of Iceland apparently 'jumped' $50 \mathrm{~km}$ westwards to leave the remnant Fjallgarður ridge (Helgason, 1984); the active rift zone may have narrowed at the end of the last glaciation, or volcanic activity may have shifted from one fissure swarm to another (Bourgeois et al., 1998). Modern measurements show that north-central Iceland is continuing active rifting (Angelier et al., 1997; Garcia et al., 2003). The deformation rate estimated for the entire rifting zone of Iceland is a variable 1.5 to $15 \mathrm{~cm} \cdot \mathrm{y}^{-1}$ over the last 10,000 years (Dauteuil et al., 2001), or more precisely $1.79 \mathrm{~cm}^{-1}{ }^{-1}$ for the northern volcanic zone (NVZ) (Guðmundsson, 2000). Specific rifting events create much more rapid land disturbances, including earthquakes and hillslope failures. For example, at Krafla between 1975 and 1984, a spreading segment widened by 4-6 $\mathrm{m}$, and elevation changes of up to 2 m were detected (Björnsson, 1985). Rifting episodes and earthquakes in north-central Iceland have produced large boulders by creating shallow escarpments and by destabilising hilltops and hillslopes.

A regional reconstruction including radiocarbon dates from Axarfjörður suggests that the last ice sheet margin lay beyond the present mouth of the Jökulsá á Fjöllum at 10,500 BP, but by $9600 \mathrm{BP}$ had retreated $70 \mathrm{~km}$ inland (Norðdahl, 1990). Small glacier advances have occurred in north-central Iceland at 5000 BP (Guðmundsson, 1997; Kirkbride and Dugmore, 2001, 2006). Ice sheet retreat and downwasting in north-central Iceland deposited boulder-rich moraines either in coherent ridges or as a sparse 'drift', or 'sheet' or 'veneer' deposit. Holocene deglaciation changed, and continues to change, the style of volcanic activity (e.g., Slater et al., 1998; Hooper et al., 2011) and has consequently produced a wide variety of landforms related to ice-volcano interactions (Carrivick et al., 2009a). The early Holocene was therefore a time of significant landscape instability; partly through the production of volcanic edifices, partly through paraglacial debuttressing processes, and partly through exposure of the landscape to periglacial processes. Indeed, Ólafsdóttir and Guðmundsson (2002) identified two substantial landscape degradation phases in the northeast of Iceland, at around 5000 and $2500 \mathrm{BP}$. Such landscape instability and landscape degradation (Käyhkö et al., 2002) would be partly manifest in the production and modification of large boulders and boulder-rich deposits.

Fluvial deposits are commonly found on mountainsides at a variety of elevations above the Jökulsá á Fjöllum jökulhlaup landscape. These deposits reflect deposition from localised snowmelt runoff or ice-contact deposition during deglaciation. During the mid and late Holocene in north-central Iceland, erosion and weathering of both ice sheet moraine material and of volcanic deposits could have produced large boulders as a lag deposit through the removal of finergrained sediments. Weathering in the central highlands of Iceland is dominantly insolation weathering and freeze-thaw or frost-shattering. Both of these weathering processes can produce large boulders of basalt, hyaloclastite, and hyalotuff. This weathering is determined by the strongly continental climate that produces low precipitation, a large annual temperature range, and very few days of autumn and spring (Arnalds et al., 2011). The climate is largely a result of local (boundary layer) controls upon the weather. Vatnajökull probably determines the prevailing wind direction (southwesterly) within the central highlands and promotes a high pressure field and strong katabatic winds (Ashwell, 1986; de Ruyter de Wildt et al., 2003; Arnalds et al., 2011). The Ódáðahraun is a vast expanse of basalt sand that is a semidesert characterised by an almost total lack of vegetation or 
well-developed soil cover, vast lava flows, deflated bedrock forms, ventifacted bedrock surfaces and large boulders, mixed-genesis gravel sheets, dunes and bars, and aeolian sand (Käyhkö et al., 2002; Alho, 2003; Arnalds et al., 2011).

Overall, large boulders in north-central Iceland have clearly been produced by (i) ice sheet glaciation that has eroded valley floors, eroded hillsides, and deposited boulders and sediments; (ii) subglacial and subaerial volcanism, which has created basalt ridge edifices that are highly friable and collapse to produce large boulders; (iii) tectonic rifting that has produced escarpments, ridges and hillslope failures that include boulder deposits, (iv) jökulhlaups that have eroded and redistributed boulders, and $(\mathrm{v})$ weathering that has degraded hillsides and hill tops (Carrivick and Twigg, 2005) to expose and re-shape boulders. Unfortunately Howard et al. (2012) apparently did not consider or refute any alternative hypotheses for the genesis of large boulders that they used as palaeostage indicators (PSIs).

\section{Criteria for identifying jökulhlaup impacts}

A set of criteria for each competing hypothesis of formation is necessary to suggest the genesis of landforms and sediments, including large boulders. A suitable set of criteria exists for landforms of outburst floods in rifting volcanic terrain (Carrivick et al., 2004b) and for outburst flood sediments (Marren, 2002, 2005; Carrivick et al., 2004a, 2007; Cassidy et al., 2004; Marren and Schuh, 2009). Howard et al. (2012) gave no indication that they used these criteria, nor any similar criteria of their own. These criteria are already published and so are not presented here for brevity. However, by way of example, a hypothesis of a genesis of ice sheet glaciation for a landform can be refuted with observations of (i) localised, intricate, and small-scale patterns of erosion and deposition; (ii) smoothed stoss side and smoothed lee side bedrock bumps, and (iii) clusters of subrounded and preferentially orientated boulders; especially imbricated boulders. These landform properties refute ice sheet glaciation genesis as a hypothesis because (i) ice sheet glaciated bumps have striated stoss side and plucked lee side faces (further discussion and references in Benn and Evans, 2010), (ii) ice sheets have landscape-scale effects (Stokes and Clark, 1999, 2001), and (iii) glacial erratic dispersal trains contain randomly located and orientated angular clasts (further discussion in Benn and Evans, 1998), respectively. Criteria for hypotheses of ice sheet glaciation, subglacial volcanic, subaerial volcanic, tectonic, periglacial, hillslope and aeolian processes are detailed in full in Carrivick (2005). The criteria for outburst floods in volcanic terrain (Carrivick et al., 2004a,b) are compiled under the conditions of scale and of association. Association is included because it is exceptionally difficult to accurately interpret the genesis of a landform or sedimentary sequence from a single point observation. Observations need to be linked together and considered with respect to each other (e.g., Carling et al., 2009), and this crucial geomorphological principle seems to be omitted from the Howard et al. (2012) study.

\section{Discussion of data presented by Howard et al. (2012)}

Given the overview of different processes by which large boulders could exist in the north-central Icelandic landscape and given the extraordinary importance attributed to some boulders by Howard et al. (2012), we are surprised that they (i) do little to clearly define definitively the fluvial origin of their field data, and (ii) have very little data of use for their hydraulic modelling. Specifically, they employ a step-backwater hydraulic modelling method that depends on the specification of high-water levels. In the case of a past flood, evidence of high-water levels is usually provided by 'palaeostage indicators' (PSIs) (Carrivick and Rushmer, 2006); the term 'trimline' is erroneously applied to PSIs by Howard et al. (2012) because their data points neither pertain to erosional landforms nor to a series of 'joined-up' or 'spatially-linked' sites. The step-backwater model used by Howard et al. (2012) determined a map of the inundation of the flood and also the peak discharge of the flood, and therefore it is imperative for them to robustly defend the location, situation, nature, and genesis of these PSIs. Howard et al. (2012) used large boulders as PSIs, but these boulders are not described in terms of lithology, shape, size, orientation, or situation. For example, in their Fig. $3 \mathrm{~A}$ the boulder is not convincingly of fluvial origin (it is not imbricated); in their Fig. 3B how is it known that the boulders were deposited from suspension and what does 'dispersion of water' mean? Could boulders really be deposited from washload? On p. 7 they make reference to 'washload scouring' by 'hyperconcentrated flows' without justification (from sedimentary observations); their Fig. 3C shows no evidence of fluvial erosion, only exfoliation; the bar in Fig. 3D is attributed to 'suspended sediment deposition' but this is not supported with any sedimentological or stratigraphical data.

In terms of the quantity of data useful to their modelling, Howard et al. (2012) identified a single data point near Moðrudalur that is not inside the domain of their model according to their Figs. 2, 7 and 10. Their Ferjufjall data point is actually not a data point at all because by their own admission there is no evidence of high magnitude fluvial processes at that location. Many reasons exist of course why high water evidence may not be created nor preserved at a locality. Howard et al. (2012) then contradicted themselves by suggesting that there is evidence; that the smooth undulating topography on the top of Ferjufjall is caused by fluvial erosion sustained under large water depths. We contend that the undulating topography is in fact a primary feature of subglacially erupted palagonite and that the same morphology can be seen on subglacially erupted edifices well away from the Jökulsá á Fjöllum. We also contend that there is very clear evidence of jökulhlaup flow around Ferjufjall and that this flow can be convincingly mapped from the distribution of diagnostic erosional and depositional landforms (our Fig. 1A). The third conclusion of Howard et al. (2012) of a discharge estimate based on the premise that Ferjufjall was completely inundated is thus in our opinion void.

We consider that the field observations presented by Howard et al. (2012) on the northern and eastern flanks of Mt. Herðubreið cannot be used to delimit either the lateral or vertical extent of a palaeoflood. The small ridge in their Fig. 3D that they interpret as a prominent 'bar feature' cannot be identified on aerial imagery of this location (our Fig. 1B). We suggest that the eastern and northern flanks of Herðubreið predominantly consist of primary volcanic topography, partially mantled by slope materials that have been soliflucted, washed, and avalanched from the volcanic edifice (our Fig. 1B). The presence of rounded clasts alone is not sufficient to invoke a jökulhlaup because palagonite conglomerates provide a ready supply of rounded clasts. Howard et al. (2012) therefore apparently had absolutely no downstream constraint whatsoever on their modelled water surface elevation. At the upstream end of their model domain, most of the PSI evidence in their figures is either on the contemporary river bank or part of the trim line mapped and analysed by Alho et al. (2005); i.e. of a smaller flood than they proposed. Additionally, all of their upstream PSIs are located on the western side of the Jökulsá á Fjöllum thalweg and so do not appear to delimit a single complete cross section. The 'new' evidence presented by Howard et al. (2012) is therefore exceptionally disparate and limited to the northeastern flank of Herðubreið. Overall, the PSIs as presented by Howard et al. (2012) are insufficient in quality and quantity for confidence in their modelling. This determination renders their first conclusion, that new evidence is presented of floods at higher elevations, highly speculative at best.

\section{Discussion of the hydraulic modelling presented by Howard et al. (2012)}

Some of the vague assumptions and logic employed by Howard et al. (2012) are not just imprecise writing, which is unfortunately a feature of their paper, but have fundamental implications for the 

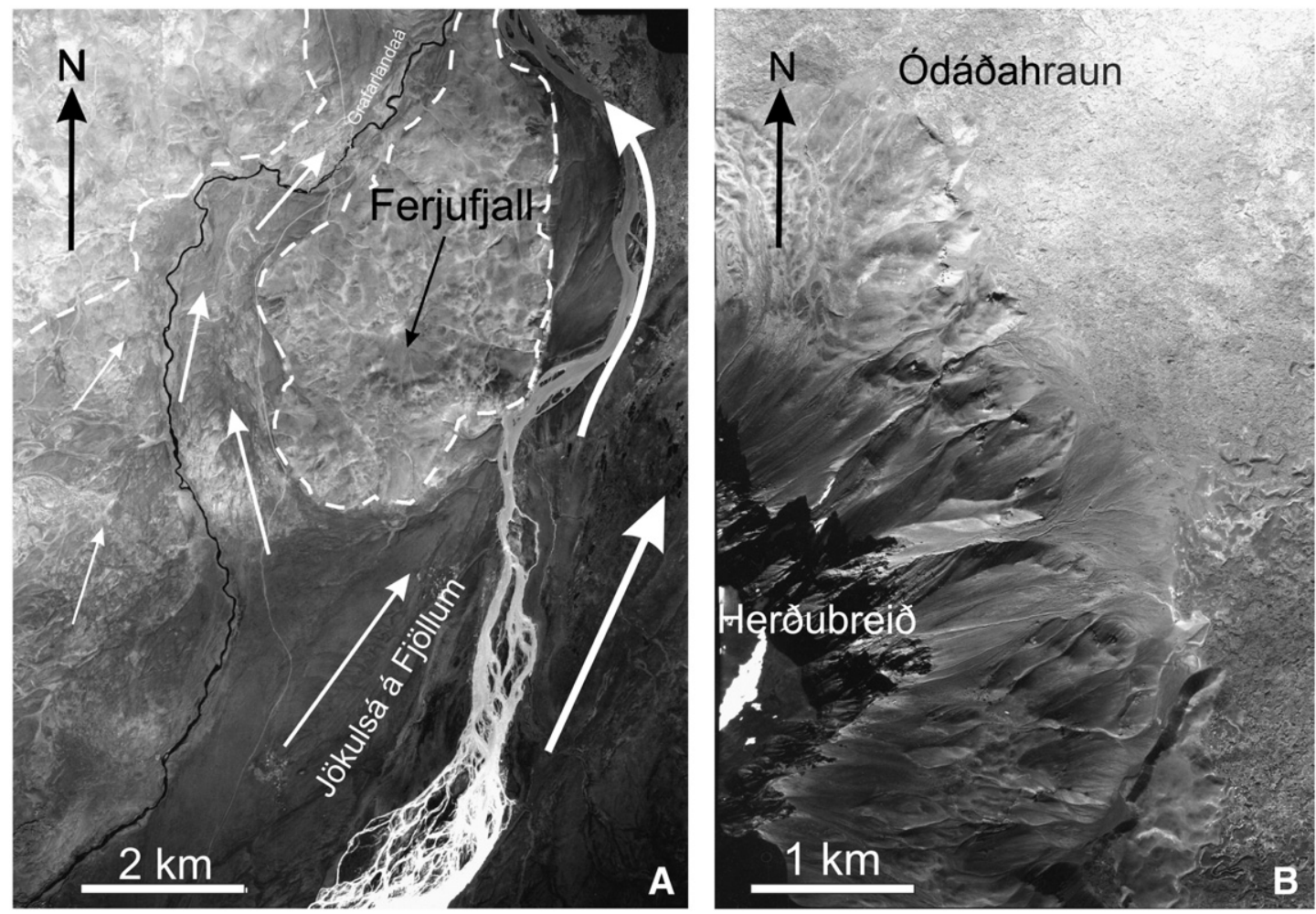

Fig. 1. Detail of flood limits around Ferjufjall (A) and of the north-eastern flanks of Herðubreið (B).

validity of their methods. As regards the imprecise writing, two statements need to be corrected immediately. Firstly, Howard et al. (2012) referred to a 14 year-old paper by Miller and Cluer (1998) to say that it is inconclusive whether the complexity of 2D modelling is justified for palaeoflood analyses. Yet it is a fact that (i) technology has developed a lot since then and (ii) Alho and Aaltonen (2008) specifically addressed this issue using the Jökulsá á Fjöllum as an example. Secondly, Howard et al. (2012) erroneously cited Carling et al. (2003) with respect to the Missoula floods. They referred to an Altai flood discharge of $18 \times 10^{6} \mathrm{~m}^{3} \mathrm{~s}^{-1}$ and attributed this estimate to Herget (2005). In fact, Herget (2005) recognised that the Baker et al. (1993) estimate of $18 \times 10^{6} \mathrm{~m}^{3} \mathrm{~s}^{-1}$ was based on a very limited number of cross sections that were within the location of the ice-dam itself. Thus, Herget remodelled the Altai flood using revised multiple cross sections located downstream of the ice dam and confirmed the peak discharge as $10 \times 10^{6} \mathrm{~m}^{3} \mathrm{~s}^{-1}$ using both 1D and 2D steadyflow methods. Note, Carling et al. (2010) recently revisited modelling this Altai flood but with 1D and 2D unsteady-flow methods and, considering uncertainty, confirmed the peak discharge as most likely the same as that estimated by Herget (2005).

Regarding the validity of the methods employed by Howard et al. (2012), they stated in their second conclusion that their model results correlated well with previous peak discharge estimates and flood inundation maps and that this calibrates their model. No correlation is presented, we are not told which previous studies or which peak discharge estimates (several are given herein in Table 2), and in step-backwater modelling PSI field data merely parameterises the model. Furthermore, the step-backwater modelling method relies on the model being iteratively altered to best-fit the PSI and so it is therefore no surprise that the model correlates well with its input data. Calibration of hydraulic modelling is a different process altogether and cannot be achieved by comparing model results to previous model results. Indeed, whilst they have a subsection entitled 'errors and uncertainties', there is (in our opinion) no such analysis. The procedures used to set up the model are vague and there is no uncertainty analysis of the PSIs. They seem to have adopted the default expansion and contraction coefficient values without evaluation and a reader is left hanging with the statement "which is consistent with the approach used here.' They vaguely state that they 'use a range of trimline heights that bound our observations...' but does this mean that they used the upper, lower or indeed the median values?

Howard et al. (2012) devoted a large proportion of their paper to discussing Manning's $n$ value as an input to their model and report the use of different Manning's $n$ values between 0.03 and 0.075 for channel and overbank sections. Ultimately, according to their Table 1, they decided upon values of 0.035 and 0.065 , which curiously are the same as that used by Alho et al. (2005). Having the same values as Alho et al. (2005) partly renders their lengthy discussion superfluous. More importantly, whilst Howard et al. (2012) seemed to acknowledge that they should have varied Manning's $\mathrm{n}$ in Section 3.4 they failed to do this. This omission is a problem because the stage-dependant nature of Manning's $n$ is well known; by way of example, the paper by Van et al. (2012) highlights the importance of varying Manning's $n$ as stage changes. Whilst Alho et al. (2005) used Manning's $n$ values for a flood of up to $40 \mathrm{~m}$ flow depth, Howard et al. (2012) suggested floods of $160 \mathrm{~m}$ and $210 \mathrm{~m}$ deep. The fact that the longitudinal velocity (and hence power and shear stress) calculated by Howard et al. (2012) in their Fig. 12 showed far less variability than that calculated by Alho et al. (2005) in their Fig. 5 is further evidence of this 'drowning' of the effect of form roughness. Carrivick (2010) has recently conducted a series of experiments that include an attempt to quantify and to conceptualise some of the properties of relative roughness in clear-water outburst floods. In our opinion, this problem with the Manning's $n$ specification, alongside the problems as described above with the PSIs that parameterise the model, makes Howard et al.'s (2012) fourth conclusion; an 'upper limit' peak discharge that is determined by hydraulic modelling based on sparse and few PSIs and on incorrect Manning's $n$ values, very doubtful.

Whereas Alho et al. (2005) modelled $140 \mathrm{~km}$ of the Jökulsá á Fjöllum routeway and Alho et al. (2007) modelled $120 \mathrm{~km}$ of the 
Jökulsá á Fjöllum routeway, Howard et al. (2012) only modelled a $24 \mathrm{~km}$ long reach of the middle part of the Jökulsá á Fjöllum (our Fig. 2). This focus on a single reach in the middle of the routeway is problematic because (i) hydraulics are exceptionally variable longitudinally, as emphasised by Figs. 5 and 6 of Alho et al. (2005) and more recently in a study at Mt Ruapehu by Carrivick et al. (2009b, 2010), and (ii) hydraulics modelled in a subcritical step-backwater model entirely depend on the initiated downstream boundary conditions. The Howard et al. (2012) model has no downstream PSI data, as discussed above; the Möðrudalur PSI is outside of the model domain; and the Ferjufjall location is not a PSI. The Howard et al. (2012) model upstream boundary is at Herðubreið, and this cross section (like the downstream boundary) does not represent the modelled reach in terms of geometry; flow lines will not be parallel, and thus the assumption of hydrostatic distribution of pressure through this cross section is violated. Therefore, the Howard et al. (2012) model is very unlikely to satisfy the hydraulic assumptions of steady (in time) and 'gradually-varied' (in space) flow and will calculate erroneous head loss between adjacent cross sections. This problem could explain why Howard et al. (2012) have a water surface elevation change of $\sim 100 \mathrm{~m}$ (from $>680$ to $\sim 580 \mathrm{~m}$ in their Fig. 12A), where channel elevation decreased by just $\sim 30 \mathrm{~m}$. For note, the model of Alho et al. (2005) had the water surface gradient more or less matching the channel gradient for the same reach. A direct comparison of longitudinal variation in peak discharge presented by Alho et al. (2005) and Howard et al. (2012) is given in Fig. 2 to emphasise the discrepancies between channel elevations and water surface elevations.

Overall, the modelling presented by Howard et al. (2012) seems to have fallen for the very problems detailed by Carling et al. (2003), whom they cite, but that are addressed more fully by Cao and Carling (2002a,b), whom they do not cite. These are namely (and to paraphrase) that 'the quality of hydraulic models is often doubtful because of (i) poor assumptions in model formulation; (ii) simplified numerical procedures; (iii) omission of sediment relationships or implementation of sediment relationships of questionable validity; and (iv) problematic model calibration and verification'.

\section{Implications of the calculation of a very large peak discharge}

When conducting palaeoflood studies of large floods it is necessary to consider the implications of calculations of very large, albeit sudden, discharges (O'Connor and Baker, 1992). Calculating the peak discharge of a flood to be more than twice the peak discharge of any other must give pause for thought on several counts. Firstly, the evidence needs checking very carefully as discussed above. Secondly, a realistic source and trigger needs to be identified to generate the necessary volume and peak discharge. Regarding the first of these points, if a flood of $22-45 \times 10^{6} \mathrm{~m}^{3} \mathrm{~s}^{-1}$ occurred it is hard to imagine how the Jökulsá á Fjöllum landscape would look today. Alho et al. (2005), Carrivick et al. (2004a,b) and Carrivick (2006, 2007a,b) have quantitatively linked jökulhlaup hydraulics along the Jökulsá á Fjöllum to landforms and sediments matching flood geomorphology to 'hydraulic envelopes'; usually flow depth / flow velocity ratios (Carrivick, 2007b). The same has been done for the Missoula palaeofloods by O'Connor (1993), Benito (1997) and Alho et al. (2010), and for modern outburst floods at Mt. Ruapehu, New Zealand, by Carrivick et al. (2009b, 2010). All of the hydraulic envelopes in these studies considered that both erosional and depositional landforms (i) belong to a hierarchy (e.g. Carrivick, 2007a,b); and (ii) evolve temporally (Carrivick et al., 2011). The calculations of velocity and power produced by Howard et al. (2012) are so far outside these established flow depth/ flow velocity ratio envelopes, that a flood of the magnitude suggested might have simply comprised cavitation processes over the majority of the routeway. Therefore, Howard et al. (2012) are implying that the subtleties and variety of erosional and depositional landforms and sediments that have been attributed to jökulhlaups along the Jökulsá á Fjöllum (Table 1) must belong to smaller, late Holocene jökulhlaups (Table 2); this is not supported by the geochronological work that has been completed to date (e.g., Kirkbride et al., 2006) (Table 2).

For the second point, Alho et al. (2007) built upon the work of Alho et al. (2005) and determined that a hypothetical hydrograph with a volume of one-third that of the Barðabunga caldera could produce a peak discharge of $0.18 \times 10 \mathrm{~m}^{3} \mathrm{~s}^{-1}$ along the Jökulsá á Fjöllum. In contrast, Howard et al. (2012) appeared to make some rather unrealistic assumptions as to how a peak discharge of $2.2-4.5 \times 10^{7} \mathrm{~m}^{3} \mathrm{~s}^{-1}$ could have been produced. They do not give a volume estimate for their reconstructed floods and so we here consider that because the Altai $10 \times 10^{6} \mathrm{~m}^{3} \mathrm{~s}^{-1}$ flood had a total volume of $\sim 695 \mathrm{~km}^{3}$ (Herget, 2005; Carling et al., 2010) by the same (albeit rough) scaling a reservoir volume of $\sim 1529 \mathrm{~km}^{3}$ would be needed to produce the (smaller) $22 \times 10^{6} \mathrm{~m}^{3} \mathrm{~s}^{-1}$ flood proposed by Howard et al. (2012). In their Section 7, Howard et al. (2012) seemed to realise that there was a problem with finding this volume of water, but without any evidence at all their suggestion of a combination of sources (including unsupported hypotheses of extremely large proglacial lakes and subglacial lakes as well as subglacial volcanism) is a very weak argument. This supposition is not a finding of their research and they give no citation for the source of this information. Howard et al. (2012) did not suggest how either individually or in combination all these lakes might have drained

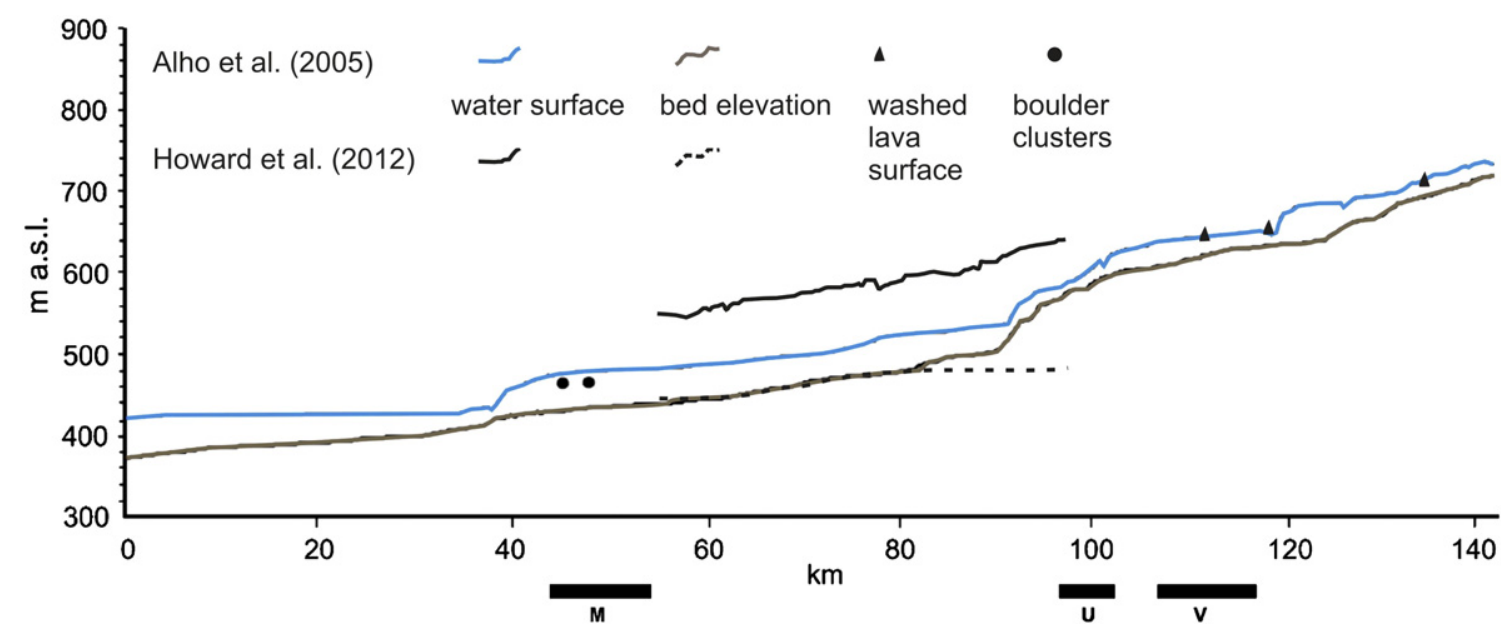

Fig. 2. Comparison of bed elevation and water surface elevation suggested by Howard et al. (2012) and Alho et al. (2005) for large jökulhlaups along the Jökulsá á Fjöllum. 
simultaneously. According to Björnsson and Pálsson (2008), the volume of Vatnajökull in the year 2000 was $3100 \mathrm{~km}^{3}$, corresponding to $2790 \mathrm{~km}^{3}$ of freshwater. Using our estimate of $\sim 1529 \mathrm{~km}^{3}$ of floodwater, the Howard et al. (2012) jökulhlaup would require (in a matter of hours) about $55 \%$ of the present-day water-equivalent volume of Vatnajökull. We wonder how that much ice could have been in the Jökulsá á Fjöllum catchment at any stage during the Holocene? Furthermore, a flood of the magnitude suggested by Howard et al. (2012) would have surely been detected in offshore deposits and it would have increased global sea level by $\sim 4 \mathrm{~mm}$ !

\section{Conclusions}

Overall, Howard et al. (2012) claimed to have found evidence of the largest flood on Earth. In our opinion, a claim of that grandeur and potential significance to understanding Icelandic landscapes requires very careful documentation of the evidence. We consider that the genesis of large boulders used by Howard et al. (2012) as PSIs is ambiguous. We suggest that the position and location of the boulders is insufficient to parameterise a step-backwater hydraulic model and that it remains unproven as to whether Ferjufjall was over-topped by a flood because there is no evidence preserved there. We propose that their modelling is flawed because Manning's $n$ is treated as a fixed quantity and because only a single middle reach of the Jökulsá á Fjöllum is modelled and because the PSIs were insufficient in number and quality. We are not convinced that Howard et al. (2012) provided a convincing explanation for generating the volume of water necessary for such a large flood. We cannot envisage how such a large flood could conceivably have been sourced and triggered from northern Vatnajökull.

\section{Acknowledgements}

Matthew Roberts, Helgi Björnsson, and Vic Baker are thanked for their knowledgeable comments on a draft of this manuscript.

\section{References}

Alho, P., 2003. Land cover characteristics in NE Iceland with special reference to jökulhlaup geomorphology. Geografiska Annaler 85A (3-4), 213-227.

Alho, P., Aaltonen, J., 2008. Comparing a 1D hydraulic model with a 2D hydraulic mode for the simulation of extreme glacial outburst floods. Hydrological Processes 22, $1537-1547$.

Alho, P., Russell, A.J., Carrivick, J.L., Käyhkö, J., 2005. Reconstruction of the largest jökulhlaup within Jökulsá á Fjöllum river, NE Iceland during Holocene. Quaternary Science Reviews 24, 2319-2334.

Alho, P., Roberts, M.J., Käyhkö, J., 2007. Estimating the inundation area of a massive, hypothetical jökulhlaup from northwest Vatnajökull, Iceland. Natural Hazards 41, 21-42

Alho, P., Baker, V.R., Smith, L.N., 2010. Paleohydraulic reconstruction of the largest Glacial Lake Missoula draining(s). Quaternary Science Reviews 29, 3067-3078.

Angelier, J., Bergerat, F., Dauteuil, O., Villemin, T., 1997. Effective tension-shear relationships in extensional fissure swarms, axial rift zone of northeastern Iceland. Journal of Structural Geology 19, 673-685.

Arnalds, O., Gisladottir, F.O., Orradottir, B., 2011. Determination of aeolian transport rates of volcanic soils in Iceland. Geomorphology 167-168, 4-12.

Ashwell, I.Y., 1986. Meteorology and duststorms in central Iceland. Arctic and Alpine Research 18, 223-234

Baker, V.R., 2002. High-energy megafloods: planetary settings and sedimentary dynamics. In: Martini, P., Baker, V.R., Garzon, G. (Eds.), Flood and Megaflood Processes and Deposits: Recent and Ancient Examples. : IAS Special Publication, 32. Blackwell, Oxford, UK, pp. 3-15.

Baker, V.R., Benito, G., Rudoy, A.N., 1993. Palaeohydrology of late Pleistocene superflooding Altay Mountains, Siberia. Science 259, 348-350.

Benito, G., 1997. Energy expenditure and geomorphic work of the cataclysmic Missoula flooding in the Columbia River gorge, USA. Earth Surface Processes and Landforms 22, 457-472.

Benn, D.I., Evans, D.J.A., 1998. Glaciers and Glaciation. Arnold, London, (734 pp.).

Benn, D.I., Evans, D.J.A., 2010. Glaciers and Glaciation. Hodder Education, London, UK (816 pp.).

Björnsson, A., 1985. Dynamics of crustal rifting in NE Iceland. Journal of Geophysical Research 90 (B12), 10151-10162.

Björnsson, H., Pálsson, F., 2008. Glaciers in Iceland. Jökull 58, 365-386.

Bourgeois, O., Dauteuil, O., Van Vliet-Lanoe, B., 1998. Pleistocene subglacial volcanism in Iceland: tectonic implications. Earth and Planetary Science Letters 164, 165-178.
Cao, Z., Carling, P.A., 2002a. Mathematical modelling of alluvial rivers: reality and myth. Part 1: general review. Water and maritime engineering. Proceedings of the Institution of Civil Engineers 154, 207-219.

Cao, Z., Carling, P.A., 2002b. Mathematical modelling of alluvial rivers: reality and myth. Part 2: special issues. Water and maritime engineering. Proceedings of the Institution of Civil Engineers 154, 297-307.

Carling, P.A., Kidson, R., Cao, Z., Herget, J., 2003. Palaeohydraulics of extreme flood events: reality or myth. In: Gregory, K.J., Benito, G. (Eds.), Palaeohydrology; Understanding Global Change. Wiley, Chichester, UK, pp. 325-336.

Carling, P.A., Burr, D.M., Johnson, T.F., Brennand, T.A., 2009. A review of open-channel megaflood depositional landforms on Earth and Mars. In: Burr, D.M., Carling, P.A., Baker, V.R. (Eds.), Megaflooding on Earth and Mars. Cambridge University Press, Cambridge, UK

Carling, P.A., Villanueva, I., Herget, J., Wright, N., Borodavko, P., Morvan, H., 2010. Unsteady 1D and 2D hydraulic models with ice dam break for Quaternary megaflood, Altai Mountains, southern Siberia. Global and Planetary Change 70, 24-34.

Carrivick, J.L., 2005. Characteristics and impacts of jökulhlaups (glacial outburst floods) from Kverkfjöll, Iceland. unpublished PhD thesis (Keele University).

Carrivick, J.L., 2006. 2D modelling of high-magnitude outburst floods; an example from Kverkfjöll, Iceland. Journal of Hydrology 321, 187-199.

Carrivick, J.L., 2007a. Modelling coupled hydraulics and sediment transport of a highmagnitude flood and associated landscape change. Annals of Glaciology 45, 143-154.

Carrivick, J.L., 2007b. Hydrodynamics and geomorphic work of jökulhlaups (glacial outburst floods) from Kverkfjöll volcano, Iceland. Hydrological Processes 21, 725-740.

Carrivick, J.L., 2009. Jökulhlaups from Kverkfjöll volcano, Iceland: modelling transient hydraulic phenomena. In: Burr, D.M., Carling, P.A., Baker, V.R. (Eds.), Megaflooding on Earth and Mars. Cambridge University Press, Cambridge, UK, pp. 273-289.

Carrivick, J.L., 2010. Dam break - outburst flood propagation and transient hydraulics: a geosciences perspective. Journal of Hydrology 380, 338-355.

Carrivick, J.L., 2011. Jökulhlaups: geological importance, deglacial association and hazard management. Geology Today 27, 133-140.

Carrivick, J.L., Rushmer, E.L., 2006. Understanding high-magnitude outburst floods. Geology Today 22, 60-65.

Carrivick, J.L., Twigg, D., 2005. Jökulhlaup-influenced topography and geomorphology at Kverkfjöll, Iceland. Journal of Maps 2005, 17-27.

Carrivick, J.L., Russell, A.J., Tweed, F.S., Twigg, D., 2004a. Palaeohydrology and sedimentology of jökulhlaups from Kverkfjöll, Iceland. Sedimentary Geology 172, 19-40.

Carrivick, J.L., Russell, A.J., Tweed, F.S., 2004b. Geomorphological evidence for jökulhlaups from Kverkfjöll volcano, Iceland. Geomorphology 63, 81-102.

Carrivick, J.L., Pringle, J.K., Russell, A.J., Cassidy, N.J., 2007. GPR-derived sedimentary architecture and stratigraphy of outburst flood sedimentation within a bedrock valley system, Hraundalur, Iceland. Journal of Environmental and Engineering Geophysics $12,127-143$

Carrivick, J.L., Russell, A.J., Rushmer, E.L., Tweed, F.S., Marren, P.M., Deeming, H., Lowe, O.J., 2009a. Geomorphological evidence towards a deglacial control on volcanism. Earth Surface Processes and Landforms 34, 1164-1178.

Carrivick, J.L., Manville, V., Cronin, S., 2009b. Modelling the March 2007 lahar from Mt Ruapehu. Bulletin of Volcanology 71, 153-169.

Carrivick, J.L., Manville, V., Graettinger, A., Cronin, S., 2010. Coupled fluid dynamicssediment transport modelling of a Crater Lake break-out lahar: Mt. Ruapehu, New Zealand. Journal of Hydrology 388, 399-413.

Carrivick, J.L., Jones, R., Keevil, G., 2011. Experimental insights towards geomorphic processes within dam break outburst floods. Journal of Hydrology 408, 153-163.

Cassidy, N.J., Russell, A.J., Pringle, J.K., Carrivick, J.L., 2004. GPR-derived architecture of large-scale icelandic Jökulhlaup deposits, North-East Iceland. In: Slob, E., Yarovoy, A., Rhebergen, J. (Eds.), Proceedings of the Tenth International Conference on Ground Penetrating Radar, June 21-24, 2004. DELFT, The Netherlands, pp. 581-584.

Chapman, M.G., Hare, T.M., Russell, A.J., Guðmundsson, M.T., 2003. Possible Juventae Chasma subice volcanic eruptions and Maja Valles ice outburst floods on Mars: implications of Mars Global Surveyor crater densities, geomorphology, and topography. Journal of Geophysical Research 108, 5113.

Dauteuil, O., Angelier, J., Bergerat, F., Verrier, S., Villemin, T., 2001. Deformation partitioning inside a fissure swarm of the northern Icelandic rift. Journal of Structural Geology 23, 1359-1372.

de Ruyter de Wildt, M.S., Klok, E.J., Oerlemans, J., 2003. Reconstruction of the mean specific mass balance of Vatnajökull (Iceland) with a seasonal sensitivity characteristic. Geografiska Annaler 85A, 57-72.

Garcia, S., Arnaud, N.O., Angelier, J., Bergerat, F., Homberg, C., 2003. Rift jump process in northern Iceland since $10 \mathrm{Ma}$ from ${ }^{40} \mathrm{Ar} /{ }^{39} \mathrm{Ar}$ geochronology. Earth and Planetary Science Letters 214, 529-544.

Geirsdóttir, A., Eiriksson, J., 1994. Growth of an intermittent ice sheet in Iceland during the Late Pliocene and early Pleistocene. Quaternary Research 42, 115-130.

Geirsdóttir, Á., Miller, G.H., Axford, Y., Ólafsdóttir, S., 2009. Holocene and latest Pleistocene climate and glacier fluctuations in Iceland. Quaternary Science Reviews 28, 2107-2118.

Guðmundsson, H.J., 1997. A review of the Holocene environmental history of Iceland. Quaternary Science Reviews 16, 81-92.

Guðmundsson, A., 2000. Dynamics of volcanic systems in Iceland: example of tectonism and volcanism at juxtaposed hot spot and mid-ocean ridge systems. Annual Review of Earth and Planetary Sciences 28, 197-240.

Helgason, J., 1984. Frequent shifts of the volcanic zone in Iceland. Geology 12, 212-216.

Helgason, J., 1987. Jarðfræðirannsóknir á Vatnasviði Jökulsár á Fjöllum við Möðrudal. Report OS-87005/VOD-01: Orkustofnun Reykjavík.

Herget, J., 2005. Reconstruction of Pleistocene ice-dammed lake outburst floods in the Altai Mountains, Siberia. Special Paper 386, U.S. Geological Society of America. (118 pp.). 
Hooper, A., Ófeigsson, B., Sigmundsson, F., Lund, B., Einarsson, P., Geirsson, H., Sturkell, E., 2011. Increased capture of magma in the crust promoted by ice-cap retreat in Iceland. Nature Geoscience 4, 783-786.

Hovius, N., Lea-Cox, A., Turowski, J.M., 2008. Recent volcano-ice interaction and outburst flooding in a Mars polar cap re-entrant. Icarus 197, 24-38.

Howard, D., Luzzadder-Beach, S., Beach, T., 2012. Field evidence and hydraulic modeling of a large Holocene jökulhlaup at Jökulsá á Fjöllum channel, Iceland. Geomorphology 147-148, 73-85.

Hubbard, A., Sugden, D., Dugmore, A., Norddahl, H., Pétursson, H.G., 2006. A modelling insight into the Icelandic Last Glacial Maximum ice sheet. Quaternary Science Reviews 25, 2283-2296.

Ingólfsson, Ó., 1994. A review of the environmental history of Iceland, 13,000-9000 yr BP. Journal of Quaternary Science 9, 147-150.

Käyhkö, J., Alho, P., Hendriks, J.P.M., Rossi, M., 2002. Geomorphological processes and land degradation in Ódaðahraun semi-desert, north-eastern Iceland. Jökull 51, 1-16.

Kirkbride, M.P., Dugmore, A.J., 2001. Timing and significance of mid-Holocene glacier advances in northern and central Iceland. Journal of Quaternary Science 16, 145-153.

Kirkbride, M.P., Dugmore, A.J., 2006. Responses of mountain lee caps in central Iceland to Holocene climate change. Quaternary Science Reviews 25, 1692-1707.

Kirkbride, M.P., Dugmore, A.J., Brazier, V., 2006. Radiocarbon dating of mid-Holocene megaflood deposits in the Jökulsá á Fjöllum, Iceland. The Holocene 16, 605-609.

Knudsen, Ó., Russell, A.J., 2002. Jökulhlaup deposits at the Ásbyrgi Canyon, northern Iceland: sedimentology and implications for flow type. In: Snorrason, A., Finnsdóttir, A.P., Moss, M. (Eds.), The Extremes of the Extremes: Extraordinary Floods. : Proc. of a Symp. July 2000 Reykjavík, Publ. No. 271. IAHS Press, Wallingford, Oxfordshire, UK, pp. 107-112.

Maclennan, J., Jull, M., McKenzie, M., Slater, L., Grönvold, K., 2002. The link between volcanism and deglaciation. Geochemistry, Geophysics, Geosystems 3, 1-25.

Malin, M.C., Eppler, D.B., 1981. Catastrophic floods of the Jökulsá á Fjöllum, Iceland. Reports of Planetary Geology Program - 1981, NASA Technical Memorandum 84211 Government Printing Office, Washington D.C (272-273 pp.).

Marren, P.M., 2002. Criteria for identifying high magnitude flood events in the proglacial fluvial sedimentary record. In: Snorrason, Á., Finnsdóttir, H.P., Moss, M. (Eds.), The Extremes of the Extremes: Extraordinary Floods: IAHS Publication, 271, pp. 237-241 (Wallingford, Oxfordshire, UK).

Marren, P.M., 2005. Magnitude and frequency in proglacial rivers: a geomorphological and sedimentological perspective. Earth-Science Reviews 70, 203-251.

Marren, P.M., Schuh, 2009. Criteria for identifying jökulhlaups in the sedimentary record. In: Burr, D., Baker, V.R., Carling, P. (Eds.), Megaflooding on Earth and Mars. Cambridge University Press, Cambridge, UK, pp. 225-242.
Miller, A.J., Cluer, B.L., 1998. Modeling considerations for simulation of flow in bedrock channels. In: Tinkler, K.J., Wohl, E.E. (Eds.), Rivers over Rock: Fluvial Processes in Bedrock Channels. American Geophysical Union, Washington D.C., pp. 61-104.

Norðdahl, H., 1990. Late Weichselian and early Holocene de-glaciation history of Iceland. Jökull 40, 27-50.

O'Connor, J.E., 1993. Hydrology, hydraulics and geomorphology of the Bonneville Flood. Special Papers 274, U.S. Geological Society of America, Boulder, Colorado. (83 pp.).

O'Connor, J.E., Baker, V.R., 1992. Magnitudes and implications of peak discharges from glacial Lake Missoula. Geological Society of America Bulletin 104, 267-279.

Ólafsdóttir, R., Guðmundsson, H.J., 2002. Holocene land degradation and climatic change in northeastern Iceland. The Holocene 12, 159-167.

Sæmundsson, K., 1973. Straumrákaðarklappir í kringum Ásbyrgi. Náttúrufræðingurinn 43, 52-60.

Slater, L., Jull, M., McKenzie, D., Gronvold, K., 1998. Deglaciation effects on mantle melting under Iceland: results from the northern volcanic zone. Earth and Planetary Science Letters 164, 151-164.

Stokes, C.R., Clark, C.D., 1999. Geomorphological criteria for identifying Pleistocene ice streams. Annals of Glaciology 28, 67-74.

Stokes, C.R., Clark, C.D., 2001. Palaeo-ice streams. Quaternary Science Reviews 20, 1437-1457.

Thórarinsson, S., 1950. Glacier outbursts in the river Jökulsá a Fjöllum. Náttúrufræðingurinn 20, 113-133.

Thórarinsson, S., 1959. Some geological problems involved in the hydroelectric development of the Jökulsá á Fjöllum. Report to the State Electricity Authority, Reykjavík Iceland (35 pp.)

Tómasson, H., 1973. Hamfarahlaup í Jökulsá a Fjöllum. Náttúrufræðingurinn 43, 12-34

Tómasson, H., 2002. Catastrophic floods in Iceland. In: the extremes of the extremes: extraordinary floods. In: Snorrason, A., Finnsdóttir, A.P., Moss, M. (Eds.), Proc. of a Symp. July 2000, Reykjavík, Publ. no. 271. IAHS Press, Wallingford, Oxfordshire, UK, pp. 121-126.

Van, T.P., Carling, P.A., Atkinson, P.M., 2012. Modelling the bulk flow of a bedrockconstrained, multi-channel reach of the Mekong River, Siphandone, southern Laos. Earth Surface Processes and Landforms 37 (5), 533-545.

Waitt, R.B., 1998. Cataclysmic flood along Jökulsá á Fjöllum, north Iceland, compared to repeated colossal jökulhlaups of Washington's channelled scabland. 15th Int Sedimentol. Congr., Alicante, Abstracts, pp. 811-812.

Waitt, R.B., 2002. Great Holocene floods along Jökulsá á Fjöllum, north Iceland. In: Martini, P., Baker, V.R., Garzon, G. (Eds.), Flood and Megaflood Processes and Deposits: Recent and Ancient Examples: IAS Special Publication, 32, pp. 37-51 (city, country). 